Nursing in Conflict 
Other titles by the authors

Community Care and Severe Physical Disability

Patricia Owens

Paying for Welfare, The Future of the Welfare State Howard Glennerster

\section{Planning for Priority Groups}

Howard Glennerster 


\section{Nursing in Conflict}

\section{Patricia Owens}

formerly Research Officer

London School of Economics

and

Howard Glennerster

Professor of Social Administration

London School of Economics

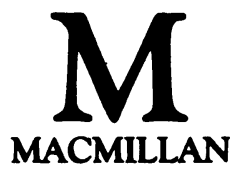


(C) Patricia Owens and Howard Glennerster 1990

All rights reserved. No reproduction, copy or transmission of this publication may be made without written permission.

No paragraph of this publication may be reproduced, copied or transmitted save with written permission or in accordance with the provisions of the Copyright Act 1956 (as amended), or under the terms of any licence permitting limited copying issued by the Copyright Licensing Agency, 33-4 Alfred Place, London WCIE 7DP.

Any person who does any unauthorised act in relation to this publication may be liable to criminal prosecution and civil claims for damages.

First published 1990

Published by

MACMILLAN EDUCATION LTD

Houndmills, Basingstoke, Hampshire RG21 2XS

and London

Companies and representatives

throughout the world

Cover pictures copyright Times Newspapers Ltd and The Mansell Collection

Typeset by Footnote Graphics, Warminster, Wilts

British Library Cataloguing in Publication Data

Owens, Patricia

Nursing in conflict.

1. Great Britain. Nursing services. Management

I. Title II. Glennerster, Howard $610.73^{\prime} 068$

ISBN 978-0-333-51202-9 ISBN 978-1-349-11177-0 (eBook)

DOI 10.1007/978-1-349-11177-0 


\section{Contents}

List of tables vi

List of figures vii

List of abbreviations viii

Acknowledgements $\quad$ ix

Introduction $\quad \mathbf{x}$

\section{Part I The background}

1 The Griffiths prescription 3

2 Nursing troubles: the external environment 20

3 Nursing troubles: internal tensions 30

4 Professions in the NHS: new perspectives 43

\section{Part II The study}

5 Implementing general management 59

6 An endangered species: nursing advice at district level 83

7 Deconstruction and reconstruction 103

8 Conversion and confusion 117

9 Pressure and change at ward level 131

10 Subjective and institutional arenas: the ward 141

11 Conclusions 159

Appendix: methodology 164

$\begin{array}{ll}\text { Bibliography } & 167\end{array}$

$\begin{array}{ll}\text { Index } & 176\end{array}$ 


\section{List of tables}

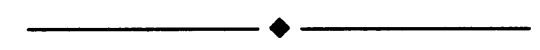

1.1 Resources and demands on the hospital and community services 1960-88

4.1 Levels of work 52

5.1 Former jobs of new general managers in $1986 \quad 59$

5.2 Major policy objectives of DGMs 61

5.3 Organizational objectives of DGMs 62

5.4 The backgrounds of UGMs in NWT in 1985-6 66

6.1 DNA roles in NWT in 1985-6 87

6.2 Changes in NWT district level nursing staff in

6.3 Hybrid roles for DNAs 92

6.4 Support for the DNAs 93

6.5 How DNAs spend their time 93

6.6 The content of NACs 101

8.1 Middle-manager titles for nurses and numbers in nine acute hospitals $\quad 119$

$\begin{array}{ll}8.2 \text { Middle managers group } & 120\end{array}$

8.3 Careers of nurse middle managers 127

$\begin{array}{lll}8.4 & \text { Future career directions } & 127\end{array}$

9.1 Characteristics of Ward Sisters 133

9.2 Ward Sister - middle manager interaction 135 


\section{List of figures}

1.1 Salmon structure 9

1.2 The post-Griffiths management structure for the NHS

2.1 The external environment 26

3.1 Nursing contradictions $\quad 30$

4.1 Stereotypical attitudes to nurses and doctors 49

4.2 Keywords from texts on nursing 50

5.1 Examples of new management arrangements in NWT

5.2 A typical district structure 65

6.1 Changes in a district organisation 85

6.2 Cycle of change in three districts 89

6.3 The nursing advisory structure in NWT 100

7.1 Pre-Griffiths nurse management 106

$\begin{array}{ll}7.2 & \text { A post-Griffiths unit structure } \\ 7.3 & 107\end{array}$

7.3 Post-Griffiths nurse - general management in a $\begin{array}{ll}\text { district unit } & 108\end{array}$

7.4 Examples of professional - management issues $\quad 110$

$\begin{array}{ll}7.5 \text { Community unit structures } & 113\end{array}$ 


\section{List of abbreviations}
A \& $\mathbf{E}$
Accident and Emergency Department
CNM
Clinical Nurse Manager
CNO
Chief Nursing Officer
CSM
Clinical Service Manager
DGM
District General Manager
DHA
District Health Authority
DMB
District Management Board
DMS
Director of Midwifery Services
DNA
District Nurse Adviser
DNAG
District Nursing Advisory Committee
DNE
Director of Nurse Education
DNS
Director of Nursing Services
D of $\mathbf{H}$
Department of Health
DQA
Director of Quality Assurance
ENB
ITU or CCU English National Board for Nursing, Midwifery and Health Visiting
NWT RHA
Intensive Care Units or Critical Care Units
RGM
North West Thames Regional Health Authority
RNAC
Regional General Manager
Regional Nursing Advisory Committee
RND
Regional Nursing Director
SM
Service Manager
SNM
Senior Nurse Manager
UGM
Unit General Manager 


\section{Acknowledgements}

-

This research was funded by North West Thames Regional Health Authority to explore nurse management functions after the Griffiths proposals. The initiators of the research were Mrs Pamela HudsonBendersky, Regional Nursing Director for NWT, and Professor Howard Glennerster, supported by the Regional General Manager, Mr David Kenny. Throughout the research period, they and members of the Steering Committee have continued to support and advise on the research.

It would be impossible to name all the individuals in NWT region at district level who have helped to make this research project possible, but we are deeply indebted to them all. Sheila Roy, Judith Sear, Frank Powell, Margaret Dorman, Bob Nessling, Brian Hambleton, June Swan, Ann Mace, David Pennell, Pat Fletcher, Joy Byatt, Diana Juniper, Meiriona William, Katherine ConwayNicholls, Judith Bryant, Anita Cox, Moira Stansfield, Jean Bailey and Aidine Phillips smoothed the way for the researchers, as did the General Managers in all districts. At LSE we wish to thank Sheila Gatiss who assisted in collecting material for the research in two districts, and Angela Kimberley, Carol Whitwill and Julie GroveHills who worked very hard to put the results into print. 


\section{Introduction}

Time present and time past

Are both perhaps present in time future, And time future contained in time past.

(T.S. Eliot)

This book is about NHS management and its relationship with the nursing profession. It is in two parts: the first describes the complex organisational, social, historical, political and economic background to the research. The second part is an account of a three-year study of nurse management in one Regional Health Authority in the period 1985-8. The study describes the organisational changes that ensued after the introduction of general management following the Griffiths report (1983).

Nurses, like other health care professionals, are often sceptical about the role of management. The activities of managers are less visible than those in the clinical area. The outcomes are less obvious or immediately experienced than they are when patients are treated on an individual basis. It is not always clear what managers do in relation to the vigorous activity that accompanies patient care at the bedside, in the hospital or out in the community.

The management task of orchestrating financial, ideological and practical elements and moving them towards the same ends is complex, but central to good professional practice. The development of common policies, philosophies and values among health care workers is a necessary part of providing a service with high standards. But, often much that is said about good management seems mere rhetoric. The definitions of what constitutes good 
management, good standards and good policies are sometimes vague and incoherent.

Nevertheless, most of us know what we mean by a 'good service', especially if we become patients. Recently, a friend of one of the authors sat with her sister who was dying in a hospital. She was in great pain and begged to be relieved of her suffering. The nurses could not administer the necessary drugs without the doctor's permission, and the doctor was unable to attend. Consequently, this friend's sister died in agony.

Good management is an essential ingredient if the patient's needs are to be adequately met by a health service. Policies about care of the dying and administration of drugs have to be devised to make a service respond with humanity. What happens at the bedside may be the outcome of poor or ineffective management systems, or overbureaucratic and authoritarian organisation.

Much emphasis in current NHS management is on financial and technical efficiency. To achieve this end, highly-skilled nurses and support workers are necessary. Finding the right balance in nursing care is itself a technical process, and cannot be divorced from issues of standards of care that can be measured and evaluated. This is a major management task.

Personal commitment of individual nurses and motivation at work are more abstract elements. However, these also need to be identified and nurtured. The nurse who is unable to control the pain of a dying patient because of unimaginative management policies will feel a failure. The primary task of managers of nurses is to help them to do their job well, to live up to the goals of the organisation, to care for patients within accepted and acceptable financial and technical parameters.

If management is well structured, and individuals are competent at their work, organisations and those who work in them will be capable of learning and adapting to new situations. We believe this book shows this complex learning process at work in a health service under great stress and undergoing profound changes. It is these positive aspects of high levels of professional and management commitment we should like to emphasise in this study.

Pat Owens 